(iD https:/ orcid.org/0000-0002-4647-2500

\title{
Pozycja pokrzywdzonego w świetle nowelizacji Kodeksu postępowania karnego z 19 lipca 2019 r.
}

\begin{abstract}
This article addresses some amendments of the Polish Code of Criminal Procedure in so far as they affect the position of the injured party. The Act of 19 July 2019 amending the Polish Code of Criminal Code provides for a number of changes relating to that participant of criminal proceedings. The paper deals with the extension of the time limit within which it is possible to withdraw a motion to prosecute, changes to the so-called subsidiary complaint, setting a deadline for questioning the injured under Articles $185 \mathrm{a}$ and $185 \mathrm{c}$ of the Polish Code of Criminal Procedure or serving the injured party with an order to pay (injunctive judgment) alongside the instructions on how to appeal against the judgment and simultaneously file a statement that the injured will act in the capacity of a subsidiary prosecution counsel. The analysis is aimed to establish whether those changes have led to the strengthening or weakening of the position of the injured party.
\end{abstract}

Keywords: injured party, criminal process, motion to prosecute, questioning, minor, subsidiary complaint, auxiliary prosecution counsel, order for payment, injunctive judgment, amendment

Najważniejszym celem procesu karnego jest realizacja postulatu sprawiedliwości poprzez jednoczesne osiągnięcie stanu sprawiedliwości materialnej oraz proceduralnej. Treścią sprawiedliwości materialnej jest doprowadzenie do słusznego zastosowania normy prawa karnego materialnego, zaś sprawiedliwość proceduralna (formalna) sprowadza się do „zapewnienia jak najwyższego stopnia prawdopodobieństwa osiągnięcia material- 
nie sprawiedliwego rezultatu (sprawiedliwości materialnej)" ${ }^{1}$. Warunkiem osiągnięcia sprawiedliwości proceduralnej jest nie tylko obiektywizm i bezstronność w dążeniu do wydania rozstrzygnięcia zgodnego z prawdą materialną, lecz również zmierzanie do osiągnięcia celów postępowania karnego przy pełnej realizacji gwarancji jego uczestników ${ }^{2}$. Niezbędne jest zatem takie ukształtowanie procedury, aby zapewnione zostały prawa zarówno oskarżonego, jak i pokrzywdzonego, bowiem miarą rzetelności procesu nie jest wyłącznie odpowiedni stopień realizacji prawa do obrony, lecz także zapewnienie należytej pozycji procesowej pokrzywdzonemu ${ }^{3}$. Wprawdzie przez wiele lat potrzeba zabezpieczenia w procesie karnym uprawnień pokrzywdzonego nie była dostrzegana przez ustawodawcę, jednak stopniowo, począwszy od Kodeksu postępowania karnego z 1969 r. aż do najnowszych nowelizacji procedury karnej, następuje wzmocnienie jego pozycji procesowej poprzez dążenie do zadośćuczynienia wyrządzonej krzywdzie oraz zapewnienia mu lepszego statusu w systemie wymiaru sprawiedliwości ${ }^{4}$. Sukcesywne rozszerzanie jego uprawnień procesowych, prowadzące do nadania mu statusu „pełnoprawnego” uczestnika postępowania skłaniać może nawet do uznania go za „czwarty wierzchołek trójkąta”, funkcjonujący obok tradycyjnie ukształtowanej triady uczestników postępowania: oskarżonego, oskarżyciela oraz sądu rozstrzygającego sprawę.

Najnowsze zmiany wprowadzone do Kodeksu postępowania karnego ${ }^{5}$ zawierają rozwiązania wpływające na pozycję zajmowaną przez pokrzywdzonego w postępowaniu karnym. Szereg modyfikacji odnoszących się do tego uczestnika procesu zmierzać ma do urzeczywistnienia zasady równości broni pomiędzy stroną czynną i bierną, przede wszystkim poprzez zaopatrzenie pokrzywdzonego w instrumenty umożliwiające oddziaływanie na przebieg postępowania ${ }^{6}$. Przedmiotem niniejszego artykułu jest analiza wprowadzonych zmian oraz próba ich oceny w kontekście sytuacji prawnej pokrzywdzonego.

1 Proces karny. Red. K. Marszat, J. ZagrodniK. Warszawa 2017, s. 35.

2 A. BIEDERMAN: Rzetelna informacja a aktywność pokrzywdzonego $w$ procesie karnym. Prok. i Pr. 2007, nr 4, s. 148.

3 A. BŁachnio-Parzych, J. Kosonoga: Rzetelny proces karny $w$ orzecznictwie Sadu Najwyższego. W: Rzetelny proces karny. Red. P. WiLIŃski. Warszawa 2009, s. 241 i nast.

${ }^{4}$ K. Dudka, G. ArtymiaK: Sytuacja pokrzywdzonego $w$ procesie karnym, ze szczególnym uwzględnieniem roli oskarżyciela positkowego i powoda cywilnego. Instytut Wymiaru Sprawiedliwości. Warszawa 2012, s. III.

${ }^{5}$ Ustawa z dnia 19 lipca 2019 r. o zmianie ustawy - Kodeks postępowania karnego oraz niektórych innych ustaw, Dz.U. 2019, poz. 1694 [dalej jako: nowelizacja].

${ }^{6}$ Uzasadnienie ustawy o zmianie ustawy - Kodeks postępowania karnego oraz niektórych innych ustaw z 18 lutego 2019 r. (Druk Sejmowy nr 465) [dalej jako: uzasadnienie], s. 3. 
W pierwszej kolejności wypada zastanowić się nad zmianą dotyczącą cofnięcia przez pokrzywdzonego wniosku o ściganie. Zgodnie z dotychczasowym brzmieniem art. $12 \S 3$ k.p.k. pokrzywdzony uprawniony jest do cofnięcia wniosku aż do otwarcia przewodu sądowego na pierwszej rozprawie głównej. W wyniku nowelizacji doszło natomiast do wydłużenia tego terminu aż do zamknięcia przewodu sądowego na pierwszej rozprawie głównej. Ustawodawca nie modyfikuje obecnie obowiązującego wymogu uzyskania zgody prokuratora, jeśli cofnięcie następuje na etapie postępowania przygotowawczego lub sądu, w przypadku gdy pokrzywdzony korzysta ze swego uprawnienia już na etapie postępowania jurysdykcyjnego. Zgodnie natomiast $\mathrm{z}$ uzasadnieniem projektu ustawy nowelizującej „,w sprawach $\mathrm{z}$ oskarżenia publicznego cofnięcie wniosku po rozpoczęciu przewodu sądowego będzie dopuszczalne tylko wtedy, gdy nie sprzeciwi się temu oskarżyciel publiczny obecny na rozprawie lub posiedzeniu". Za niezrozumiałe należy uznać przyjęte przez ustawodawcę zastrzeżenie, że „w sprawach z oskarżenia publicznego" konieczne będzie uzyskanie zgody oskarżyciela publicznego. Wszystkie bowiem sprawy o przestępstwa ścigane na wniosek z chwilą jego złożenia toczą się z urzę$\mathrm{du}$, zastrzeżenie takie nie ma zatem $\mathrm{w}$ istocie żadnego znaczenia.

Tak znaczne rozszerzenie uprawnień pokrzywdzonego, które w założeniu ustawodawcy ma wzmocnić jego pozycję procesową i zwiększyć wpływ na przebieg postępowania, w praktyce skutkować może narażeniem go na oddziaływania ze strony oskarżonego w większym niż dotychczas stopniu. Pokrzywdzony przez cały czas trwania postępowania pierwszoinstancyjnego (do zamknięcia przewodu sądowego na rozprawie głównej) będzie narażony na ewentualne naciski ze strony oskarżonego, nakłaniającego go do wycofania wniosku. Obawy te wydają się uzasadnione, w szczególności mając na uwadze katalog przestępstw ściganych na wniosek. Wystarczy wskazać chociażby na przestępstwo groźby karalnej (art. 190 k.k.), nękania (art. 190a k.k.) czy utrwalania wizerunku nagiej osoby lub osoby w trakcie czynności seksualnej (art. 191a k.k.), by z łatwością dostrzec istnienie realnego zagrożenia bezprawnym oddziaływaniem sprawcy na pokrzywdzonego. Nie bez znaczenia jest także to, że w wielu sprawach oskarżonym jest osoba najbliższa dla pokrzywdzonego, często zresztą wspólnie z nim zamieszkująca i mająca na niego duży wpływ. Tym samym możliwość wywierania presji i nakłaniania go do podjęcia decyzji i cofnięcia wniosku o ściganie jest wysoce prawdopodobna, a strach przed oskarżonym może być jedynym powodem podjęcia takiej decyzji. Można zatem wysunąć tezę, że rezultat wprowadzonej regulacji może być odwrotny do zamierzonego przez ustawodawcę. Znaczne wydłużenie terminu do cofnięcia wniosku skutkować może bowiem zwiększeniem czasowej przestrzeni, w której pokrzywdzony może być podda- 
ny bezprawnym naciskom, zwłaszcza jeśli występuje bez pełnomocnika. Wymóg uzyskania zgody sądu i oskarżyciela publicznego niekoniecznie stanowić może wystarczającą gwarancję, można bowiem wyobrazić sobie sytuację, gdy organy te nie dysponują jakimikolwiek informacjami dotyczącymi zachowania oskarżonego, które mogłyby skłonić je do podjęcia decyzji odmownej i kontynuowania postępowania.

Zgodnie z art. $12 \S 3$ k.p.k. w obecnym, znowelizowanym brzmieniu cofnięcie przez pokrzywdzonego wniosku o ściganie jest skuteczne pod warunkiem wyrażenia zgody przez prokuratora lub sąd, w zależności od etapu postępowania, oraz dodatkowo oskarżyciela publicznego obecnego na rozprawie lub posiedzeniu. Wymóg ten podyktowany jest potrzebą ochrony interesów pokrzywdzonego, zwłaszcza jeżeli nie zdaje on sobie sprawy z konsekwencji wynikających z cofnięcia wniosku ${ }^{7}$ lub gdy organ dysponuje wiedzą, że oświadczenie pokrzywdzonego obarczone jest wadą, przykładowo z uwagi na jego wymuszenie przez oskarżonego. Ustawodawca nie precyzuje przesłanek, jakimi powinny kierować się organy procesowe, odmawiając umorzenia postępowania w przypadku cofnięcia wniosku o ściganie, co rodzić może ryzyko dowolności. W piśmiennictwie przyjmuje się, że wpływ na decyzję sądu lub prokuratora powinny mieć okoliczności uwzględniane przez sąd przy wymiarze kary, a więc m.in. motywacja i sposób zachowania się sprawcy, sposób życia przed popełnieniem przestępstwa i zachowanie się po jego popełnieniu, rodzaj i rozmiar ujemnych następstw przestępstwa ${ }^{8}$.

Jak zaznaczono powyżej, cofnięcie przez pokrzywdzonego wniosku o ściganie po rozpoczęciu przewodu sądowego możliwe będzie tylko za zgodą obecnego na rozprawie lub posiedzeniu oskarżyciela publicznego. Niezbędna też będzie akceptacja decyzji przez sąd, czego wymaga ogólna reguła, zgodnie z którą cofnięcie wniosku o ściganie wymaga aprobaty organu prowadzącego postępowanie. Taka regulacja oznacza w praktyce, że oskarżyciel publiczny uzyska możliwość skutecznego „storpedowania” decyzji sądu, co prowadzi do wniosku, że ustawodawca w wyniku kolejnej regulacji wzmacnia jego pozycję kosztem uprawnień sądu, pełniącego przecież rolę organu kierującego postępowaniem na etapie jurysdykcyjnym. Nie byłaby to zresztą jedyna w Kodeksie postępowania karnego regulacja odzwierciedlająca taką tendencję ${ }^{9}$. Zgoda sądu na cofnięcie wniosku o ściganie będzie jednak wystarczająca, jeżeli prokurator nie stawi

I. Nowiкowski: Kontrola merytoryczna oświadczenia strony o odwołaniu czynności procesowej. Annales UMCS 1996, Vol. XLIII, s. 200.

${ }^{8}$ Ibidem, s. 244.

9 Zob. w szczególności art. 360 § 2 k.p.k., zgodnie z którym sprzeciw prokuratora dotyczący wyłączenia jawności rozprawy unieważnia decyzję sądu w tym zakresie i skutkuje prowadzeniem rozprawy w sposób jawny. 
się na rozprawie lub posiedzeniu (arg. a contrario art. $12 \S 3$ zd. 2 k.p.k.). W wyniku zmiany treści art. 46 k.p.k. w sprawach, w których postępowanie przygotowawcze zakończyło się w formie dochodzenia, obecność oskarżyciela publicznego nie jest obowiązkowa, chyba że przewodniczący lub sąd uznają ją za taką ${ }^{10}$. Tym samym nieobecność oskarżyciela nie będzie wstrzymywała umorzenia postępowania w przypadku cofnięcia przez pokrzywdzonego wniosku o ściganie, jeżeli decyzja ta uzyskała wcześniejszą akceptację sądu.

Skuteczne cofnięcie wniosku o ściganie po rozpoczęciu przewodu sądowego doprowadzi do powstania przeszkody procesowej określonej $\mathrm{w}$ art. $17 \S 1$ pkt 10 k.p.k., wobec czego sąd umorzy postępowanie, wydając wyrok umarzający (art. 414 k.p.k.). Przepis art. 12 \$ k.p.k. nie przewiduje w tym zakresie konieczności uwzględnienia stanowiska oskarżonego. Nie zdecydowano się na zastosowanie rozwiązania analogicznego względem przewidzianego w art. 14 \$ 2 k.p.k., zgodnie z którym cofnięcie aktu oskarżenia w toku przewodu sądowego dopuszczalne jest jedynie za zgodą oskarżonego. Tym samym w wyniku skutecznego cofnięcia wniosku o ściganie po rozpoczęciu przewodu sądowego postępowanie zostanie umorzone wyrokiem, bez względu na ewentualną wolę oskarżonego czy zamiar dowiedzenia swojej niewinności. Będzie on zatem pozbawiony możliwości uzyskania wyroku uniewinniającego, który zapewnia większą możliwość rehabilitacji niż wyrok umarzający postępowanie. Powyższy problem nabiera szczególnego znaczenia w aspekcie zmiany treści art. 632a $\$ 3$ k.p.k., zgodnie z którym w razie umorzenia postępowania ze względu na cofnięcie wniosku o ściganie po rozpoczęciu przewodu sądowego sąd może orzec, że koszty procesu ponosi w całości lub w części oskarżony. Zestawiając to z ogólną regułą wysłowioną w art. 632 k.p.k., zgodnie z którą w przypadku uniewinnienia oskarżonego koszty postępowania ponosi Skarb Państwa, brak konieczności uzyskania zgody oskarżonego może budzić pewne wątpliwości. Należy przy tym zaznaczyć, że przepis art. 632a k.p.k. w obecnym brzmieniu przewiduje możliwość nałożenia kosztów postępowania na oskarżonego także w przypadku umorzenia postępowania, ogranicza ją jednak wyłącznie do wypadków wyjątkowych. Za takie można przyjąć np. umorzenie postępowania z uwagi na znikomy stopień społecznej szkodliwości czynu bądź przedawnienie karalności, zwłaszcza jeśli było ono związane z zachowaniem oskarżonego zmierzającym do przedłużenia postępowania ${ }^{11}$. W projektowanym

${ }^{10}$ W kwestii obecności oskarżyciela publicznego na rozprawie głównej zob. A. LIMAŃSKA: Brak obowiazku stawiennictwa oskarżyciela publicznego na rozprawie $w$ kontekście podstawowych zasad procesu karnego. Probl. Prawa Karnego 2018, nr 2(28), s. 125-136.

11 K. Nowicki. W: Kodeks postępowania karnego. Komentarz. Red. J. SKorUPKA. Warszawa 2015, s. 1891. 
przepisie art. 632a § 3 k.p.k. ustawodawca nie limituje jednak możliwości obciążenia kosztami postępowania oskarżonego tylko do wyjątkowych wypadków.

Istotną zmianę $\mathrm{w}$ zakresie uprawnień pokrzywdzonego stanowi również wprowadzenie instytucji zażalenia na ponowne postanowienie o odmowie wszczęcia lub umorzeniu postępowania przygotowawczego do prokuratora nadrzędnego zgodnie z przepisem art. 330 § 2 zd. 2 k.p.k. w zmienionej treści. Na skutek złożonego przez pokrzywdzonego zażalenia na ponowne postanowienie o zaniechaniu ścigania wydane przez prokuratora prowadzącego lub nadzorującego postępowanie przygotowawcze prokurator nadrzędny jest uprawniony do uchylenia zaskarżonego postanowienia w przypadku podzielenia argumentów zażalenia bądź do utrzymania go w mocy ${ }^{12}$. W razie utrzymania w mocy zaskarżonego postanowienia pokrzywdzony, który dwukrotnie wykorzystał uprawnienia przewidziane w przepisie art. $306 \S 1$ i 1a k.p.k., zgodnie ze zmienioną treścią art. 330 § 2 zd. 3 k.p.k. może wnieść subsydiarny akt oskarżenia określony w art. 55 § 1 k.p.k. Nowelizacja wprowadza zatem dodatkowe przesłanki niezbędne do wniesienia subsydiarnego aktu oskarżenia, uzależniając to uprawnienie od zaskarżenia przez pokrzywdzonego ponownego postanowienia prokuratora o zaniechaniu ścigania karnego, wydanego w następstwie uchylenia pierwotnego postanowienia przez sąd, który uwzględnił zażalenie na pierwotne postanowienie o zaniechaniu ścigania karnego. Dopiero zatem w sytuacji, w której prokurator nadrzędny nad prokuratorem, który wydał lub zatwierdził ponowne postanowienie o zaniechaniu ścigania karnego, utrzyma to postanowienie w mocy, zaktualizuje się uprawnienie pokrzywdzonego do wniesienia skargi subsydiarnej. Dokonana zmiana zatem wprowadza dodatkowe ogniwo w postaci konieczności powtórnego zaskarżenia postanowienia o odmowie wszczęcia bądź umorzeniu postępowania przygotowawczego, tym samym wydłużając drogę do wniesienia subsydiarnego aktu oskarżenia w stosunku do aktualnego stanu prawnego.

Regulacja ta $\mathrm{w}$ istocie powraca do rozwiązania funkcjonującego przed dniem wejścia w życie ustawy z dnia 29 marca 2007 r. ${ }^{13}$ nowelizującej m.in. Kodeks postępowania karnego, jednocześnie jednak jednoznacznie wskazuje na wymóg dwukrotnego zażalenia postanowienia o zaniechaniu ścigania karnego. Tym samym brak jest wątpliwości, które pojawiały się w doktrynie na gruncie stanu prawnego istniejącego przed wejściem w ży-

12 J. ZAGRODNIK: Instytucja skargi subsydiarnej $w$ procesie karnym. Warszawa 2005, s. 264.

${ }^{13}$ Ustawa z dnia 29 marca 2007 r. o zmianie ustawy o prokuraturze, ustawy - Kodeks postępowania karnego oraz o niektórych innych ustaw, Dz.U. 2007, nr 64, poz. 432. 
cie wyżej wskazanej nowelizacji, co do uzależnienia prawa do wniesienia skargi subsydiarnej od zaskarżenia zarówno pierwotnego, jak i ponownego postanowienia o odmowie wszczęcia lub umorzeniu postępowania przygotowawczego ${ }^{14}$. W przypadku zatem kilku pokrzywdzonych tym samym czynem uprawnienie do wniesienia subsydiarnego aktu oskarżenia nabędzie wyłącznie pokrzywdzony, który zaskarżył oba postanowienia o odmowie wszczęcia lub umorzeniu postępowania przygotowawczego. Pokrzywdzony, który nie wniósł zażalenia na pierwsze z postanowień o zaniechaniu ścigania karnego, będzie uprawniony do wniesienia zażalenia na ponowne postanowienie o zaniechaniu ścigania, jednakże w sytuacji jego nieuwzględnienia przez prokuratora nadrzędnego nie będzie mógł wnieść subsydiarnego aktu oskarżenia.

Dokonując oceny niniejszego uregulowania, w pierwszej kolejności $\mathrm{z}$ pewną rezerwą można podzielić zapatrywanie zawarte $\mathrm{w}$ uzasadnieniu projektu nowelizacji, że wprowadzone rozwiązanie może służyć usunięciu ewentualnych formalnych lub merytorycznych usterek decyzji o zaniechaniu ścigania karnego, ze szczególnym uwzględnieniem wykonania wytycznych sądu uchylającego poprzednio wydane postanowienie na etapie postępowania przygotowawczego ${ }^{15}$. Zgodzić należy się z ustawodawcą, że obecnie brak jest regulacji, która gwarantowałaby kontrolę należytego zrealizowania wytycznych sądu wskazanych w postanowieniu uwzględniającym zażalenie pokrzywdzonego na postanowienie o odmowie wszczęcia lub umorzeniu dochodzenia. Ponadto, jeżeli prokurator nadrzędny dojdzie do przekonania, że zgromadzony materiał dowodowy wskazuje na niezasadność decyzji o zaniechaniu ścigania, instytucja ta będzie mogła służyć zapewnieniu realizacji praw pokrzywdzonego poprzez kontynuowanie postępowania przygotowawczego i tym samym wypełnieniu obowiązku ścigania przestępstw publicznoskargowych przez organy państwa ${ }^{16}$. W konsekwencji może to przysłużyć się zmniejszeniu liczby wnoszonych, a następnie uwzględnianych skarg subsydiarnych.

Jednocześnie należy mieć na względzie, że w niektórych przypadkach, z uwagi na nieznajomość przez pokrzywdzonego sprawcy przestępstwa, instytucja skargi subsydiarnej może $\mathrm{w}$ istocie okazać się uprawnieniem iluzorycznym. Wymaga zauważenia, że w przypadku ok. 30\% umorzeń postępowań przygotowawczych w latach 2014-2017 przyczyną umorze-

14 Szerzej na ten temat J. ZaGrodnIK: Instytucja..., s. 155-157.

15 Uzasadnienie projektu, s. 8.

16 Opinia OBSiL KRRP z 17.12.2018 r. do projektu ustawy o zmianie ustawy - Kodeks postępowania karnego oraz niektórych innych ustaw [dalej jako: Opinia OBSiL KRRP], s. 28. Źródło: http://obsil.pl/wp-content/uploads/2018/12/Opinia-OBSiL-z-17.12.2018-r.projekt-zmian-KPK.pdf [dostęp: 15.06.2020]. 
nia było niewykrycie sprawcy ${ }^{17}$. Jak wynika z przytoczonych statystyk, sprawy, w których brak danych o sprawcy przestępstwa zaważył o bycie postępowania przygotowawczego, stanowią znaczny odsetek wszystkich umorzonych na tym etapie spraw. Wobec tego wprowadzenie ponownej kontroli postanowienia o zaniechaniu ścigania karnego, wydanego po uchyleniu przez sąd pierwotnego postanowienia o odmowie wszczęcia lub umorzeniu postępowania przygotowawczego, może realnie wpłynąć na możliwość dochodzenia praw przez pokrzywdzonego, który nie ma możliwości wniesienia skargi subsydiarnej z uwagi na nieznajomość sprawcy przestępstwa. Nie można jednak tracić z pola widzenia, że w praktyce realizacja celu zamierzonego przez ustawodawcę może zostać osłabiona ze względu na obecny kształt ustrojowy prokuratury, który pozwala przypuszczać, że decyzja prokuratora nadrzędnego wydana na skutek zażalenia pokrzywdzonego najczęściej będzie tożsama w swej treści z postanowieniem prokuratora, który prowadził lub nadzorował postępowanie przygotowawcze ${ }^{18}$.

Nie sposób również pominąć pozostałych wątpliwości, jakie niesie za sobą omawiana nowelizacja. Z uwagi na wprowadzenie dodatkowej przesłanki wniesienia subsydiarnego aktu oskarżenia w postaci zażalenia na ponowne postanowienie o zaniechaniu ścigania karnego i związany z koniecznością rozpoznania tegoż środka zaskarżenia dłuższy okres oczekiwania na realizację uprawnienia z art. $55 \$ 1$ k.p.k. może spowodować u pokrzywdzonego niechęć do dochodzenia swoich praw na drodze sądowej ${ }^{19}$. W celu zminimalizowania wystąpienia przewlekłości postępowania na tym etapie wskazane byłoby wprowadzenie instrukcyjnego terminu do rozpoznania zażalenia przez prokuratora nadrzędnego na wzór postanowienia zawartego w $\$ 194$ nieobowiązującego już Regulaminu wewnętrznego urzędowania powszechnych jednostek organizacyjnych prokuratury $^{20}$. Jednocześnie wprowadzona zmiana niesie za sobą ryzyko, że w przypadku ciągłego uwzględniania przez prokuratora nadrzędnego zażaleń pokrzywdzonego na kolejne postanowienia odmawiające lub umarzające postępowanie przygotowawcze dojdzie do sytuacji, w której sprawa utknie na tym etapie postępowania ${ }^{21}$. Taka sytuacja tym samym

17 Sprawozdania Prokuratury Krajowej z działalności powszechnych jednostek organizacyjnych prokuratury w sprawach karnych. Źródło: https://pk.gov.pl/dzialalnosc/sprawo zdania-i-statystyki/ [dostęp: 15.06.2020].

${ }_{18}$ Tak też opinia Komisji Legislacyjnej przy Naczelnej Radzie Adwokackiej do projektu, s. 10.

19 Opinia OBSiL KRRP, s. 29.

20 Rozporządzenie Ministra Sprawiedliwości z dnia 11 kwietnia 1992 r. - Regulamin wewnętrznego urzędowania powszechnych jednostek organizacyjnych prokuratury, Dz.U. 1992, nr 38, poz. 163 ze zm.

21 Zob. Opinia OBSiL KRRP, s. 29. 
uniemożliwi pokrzywdzonemu realizację swoich uprawnień na drodze sądowej aż do momentu, w którym prokurator nadrzędny nie uwzględni zażalenia. Należy bowiem zauważyć, że w przypadku braku postanowienia prokuratora nadrzędnego o utrzymaniu w mocy postanowienia o zaniechaniu ścigania nie zaktualizuje się uprawnienie pokrzywdzonego do wniesienia skargi subsydiarnej. Jednocześnie taki przebieg postępowania, z uwagi na brak skuteczności dotychczasowych działań, może powodować zrezygnowanie przez pokrzywdzonego z podejmowania kolejnych czynności, mających na celu doprowadzenie do skazania sprawcy przestępstwa.

Powyższym zmianom dotyczącym warunków wniesienia subsydiarnego aktu oskarżenia towarzyszy również dodanie przepisu art. 55 § 2a k.p.k. nakładającego na organy procesowe obowiązek zawiadomienia o wniesieniu subsydiarnego aktu oskarżenia innych znanych sądowi pokrzywdzonych. Na gruncie obowiązujących regulacji pokrzywdzony, który nie wniósł aktu oskarżenia, będzie miał rzeczywistą możliwość przyłączenia się do postępowania wszczętego na skutek skargi innego pokrzywdzonego, tym samym zyskując wpływ na jego tok. Jednocześnie w przepisie art. $55 \$ 4$ k.p.k. przewiduje się powinność uzyskania zgody pozostałych pokrzywdzonych, którzy przyłączyli się do postępowania zainicjowanego na skutek skargi subsydiarnej innego pokrzywdzonego, na cofnięcie aktu oskarżenia przez oskarżyciela publicznego. Ustawodawca tym samym zrównał uprawnienia co do wpływu na bieg postępowania wszystkich pokrzywdzonych biorących udział w postępowaniu sądowym, niezależnie od tego, czy wnieśli subsydiarny akt oskarżenia, czy tylko przyłączyli się do postępowania wszczętego na skutek skargi innego pokrzywdzonego, uzasadniając to tym, że „nie ma bowiem powodu, aby temu ostatniemu pokrzywdzonemu przyznawać mniejsze uprawnienia procesowe i by nie miał on wpływu na to, czy proces w takim wypadku będzie mógł toczyć się nadal"22. Nie wchodząc w rozważania na temat braku uzasadnienia dla instytucji cofnięcia przez oskarżyciela publicznego skargi wniesionej przez oskarżyciela posiłkowego subsydiarnego, z uwagi na to, że wykraczają poza zakres niniejszego opracowania ${ }^{23}$, należy stwierdzić, że zmiany zarówno co do konieczności uzyskania zgody na cofnięcie aktu oskarżenia przez oskarżyciela publicznego także od pozostałych pokrzywdzonych uczestniczących $\mathrm{w}$ postępowaniu, jak również co do zawiadomienia pozostałych pokrzywdzonych tym samym czynem o wniesieniu skargi sub-

22 Uzasadnienie projektu.

${ }^{23}$ Zob. rozważania na temat zastrzeżeń w zakresie regulacji zezwalającej oskarżycielowi publicznemu na cofnięcie aktu oskarżenia wniesionego przez oskarżyciela subsydiarnego - J. ZAGRODNIK: Udziat prokuratora $w$ postępowaniu sądowym wszczętym przez oskarżyciela positkowego subsydiarnego. Prok. i Pr. 2017, nr 2, s. 13-16. 
sydiarnej należy ocenić pozytywnie, gdyż wzmacniają one uprawnienia pokrzywdzonych, którzy nie wnieśli samodzielnie skargi. Tym samym ustawodawca rezygnuje $\mathrm{z}$ nieuzasadnionego różnicowania sytuacji pokrzywdzonych tym samym przestępstwem.

Kolejną istotną zmianą wprowadzoną ustawą z dnia 19 lipca 2019 r. jest wprowadzenie możliwości zaskarżenia postanowienia o odmowie dopuszczenia pokrzywdzonego $\mathrm{w}$ charakterze oskarżyciela posiłkowego na podstawie przepisu art. $56 \S 2$ k.p.k. Zmiana ta zasługuje na aprobatę. Na niekonstytucyjność wskazanego przepisu zwrócił uwagę Trybunał Konstytucyjny w wyroku z dnia 16 maja 2018 r. ${ }^{24}$, w którym jednogłośnie stwierdził, że ,art. $56 \S 3$ k.p.k. w zakresie, w jakim wyłącza dopuszczalność zaskarżenia zażaleniem postanowienia wydanego na podstawie art. $56 \S 2$ k.p.k. odnoszącego się do oskarżyciela posiłkowego, jest niezgodny z art. 78 w związku z art. 31 ust. 3 Konstytucji”, podkreślając przy tym, że z uwagi na konstytutywny charakter oświadczenia pokrzywdzonego o działaniu w charakterze oskarżyciela posiłkowego, wskutek rozstrzygnięcia wydanego na podstawie przepisu art. 56 \$ k.p.k., pokrzywdzony zostaje definitywnie pozbawiony statusu strony postępowania i wszystkich związanych z tym statusem uprawnień, tym samym zostaje istotnie ograniczona obrona jego praw i interesów w procesie karnym. Pozbawienie go możliwości zaskarżenia postanowienia odmawiającego mu statusu oskarżyciela posiłkowego narusza zatem jego konstytucyjne prawo podmiotowe do zaskarżenia orzeczenia. Jednocześnie Trybunał podkreślił, że „wyłączenie zaskarżalności przedmiotowego postanowienia z pewnością nie jest najmniej uciążliwym środkiem wiodącym do osiągnięcia efektywności, sprawności czy szybkości procesu karnego", wobec czego nie spełnia przesłanki konieczności z przepisu art. 31 ust. 3 Konstytucji.

Ustawodawca jednocześnie w treści przepisu art. 56 § 1a k.p.k. jednoznacznie przesądził o niezaskarżalności postanowienia sądu, w którym odmówił oskarżycielowi posiłkowemu możliwości wzięcia udziału w postępowaniu, gdy bierze w nim już udział określona przez sąd liczba oskarżycieli.

Następną zmianą, wpływającą na uprawnienia pokrzywdzonego w procesie karnym, jest wprowadzenie przepisu art. 57 §1a k.p.k., zgodnie z którym w sprawie, w której oskarżyciel publiczny nie bierze udziału, niestawiennictwo oskarżyciela posiłkowego i jego pełnomocnika na rozprawie głównej bez usprawiedliwienia uważa się za odstąpienie od oskarżenia. Regulacja ta jest analogiczna do obecnie obowiązującego przepisu art. $496 § 3$ k.p.k. dotyczącego postępowania toczącego się z oskarżenia prywatnego. Zgodzić się należy z poglądem wskazywanym w piśmiennic-

${ }^{24}$ Wyr. TK z dnia 16 maja 2018 r., K 12/15, Dz.U. 2018, poz. 942. 
twie, że takie unormowanie wpisuje się w specyfikę postępowania zainicjowanego skargą popieraną wyłącznie przez oskarżyciela posiłkowego, którego podstawą jest przyjęcie, że ponieważ postępowanie toczy się z jego inicjatywy i w interesie, ma on w jego toku obowiązek wykazywania zainteresowania oraz dowodzenia swoich racji ${ }^{25}$. Mając na uwadze podział ról procesowych oraz formalny ciężar dowodu obciążający w takim postępowaniu oskarżyciela posiłkowego samodzielnie popierającego oskarżenie, należy uznać, że regulacja, zgodnie z którą brak stawiennictwa oskarżyciela posiłkowego lub jego pełnomocnika bez należytego usprawiedliwienia należy traktować jak odstąpienie od oskarżenia, zasługuje na aprobatę ${ }^{26}$.

Kolejną zmodyfikowaną regulacją jest zmiana w zakresie przesłuchiwania małoletnich pokrzywdzonych oraz pokrzywdzonych przestępstwami przeciwko wolności seksualnej. Stosownie do treści przepisu art. 185a $\$ 2$ zd. 1 k.p.k. w obecnie obowiązującym brzmieniu w sprawach o przestępstwa popełnione $\mathrm{z}$ użyciem przemocy lub groźby bezprawnej lub określone w rozdziałach XXIII (przestępstwa przeciwko wolności), XXV (przestępstwa przeciwko wolności seksualnej i obyczajności) i XXVI (przestępstwa przeciwko rodzinie i opiece) Kodeksu karnego przesłuchanie pokrzywdzonego, który w chwili przesłuchania nie ukończył 15 lat, w charakterze świadka przeprowadza sąd na posiedzeniu z udziałem biegłego psychologa niezwłocznie, nie później niż w terminie $14 \mathrm{dni}$ od dnia złożenia wniosku. Z kolei w pkt 26 projektu zrównano sytuację pokrzywdzonego przestępstwami określonymi w art. 197-199 k.k. (zgwałcenie, wykorzystanie bezradności lub upośledzenia oraz nadużycie zależności), który ukończył 15 lat, z pokrzywdzonym, o którym mowa w przepisie art. 185a k.p.k., poprzez wprowadzenie zasady jednokrotnego przesłuchania go w charakterze świadka tylko wówczas, gdy jego zeznania mogą mieć istotne znaczenie dla rozstrzygnięcia sprawy. Również w tym przepisie ustawodawca zastrzegł czternastodniowy termin do przeprowadzenia przesłuchania.

Regulacja art. 185a, nakazująca dokonanie przez sąd co do zasady jednorazowego przesłuchania małoletniego, który w chwili przesłuchania nie ukończył 15 lat, stanowi w istocie ochronę małoletniego pokrzywdzonego przed wtórną wiktymizacją ${ }^{27}$. Pojęcie wiktymizacji służy do opisania tego, co dzieje się z ofiarą na skutek doświadczenia przez nią różnych form przemocy. Wiktymizacja wtórna natomiast opisuje następstwa płynące z reakcji społecznego otoczenia ofiary na jej doświadczenie krzywdzenia i ze sposobów działania instytucji publicznych, których celem jest wymie-

25 B. Skowron: Kodeks postępowania karnego. Komentarz. Red. K. DudKa. LEX nr 10800.

${ }^{26}$ Tak też opinia OBSiL KRRP, s. 30.

27 C. Kulesza. W: Kodeks postępowania karnego. Komentarz. Red. K DudKa. LEX nr 10800. 
rzenie sankcji sprawcy i pomoc ofierze ${ }^{28}$. W literaturze psychologicznej wskazuje się, że następstwa w postaci wiktymizacji wtórnej stanowią wypadkową interakcji pomiędzy cechami, typem oraz formą reakcji społecznej, a także ich subiektywnym odbiorem przez ofiarę ${ }^{29}$. Przesłuchanie pokrzywdzonego może, w zależności od jego przebiegu, bardziej bądź mniej narażać go na dodatkowe przeżycia. Każdy bowiem etap postępowania sądowego, w tym i samo badanie, wiąże się z koniecznością odtworzenia przez pokrzywdzonego wspomnień związanych z zastosowaną wobec niego przemocą i stanowi ryzyko doświadczenia postępowania sądowego jako traumatycznego ${ }^{30}$. Podkreślenia wymaga, że wtórna wiktymizacja może dotyczyć wszystkich ofiar, niezależnie od ich wieku, jednakże w szczególnym stopniu dotyka małoletnich pokrzywdzonych ${ }^{31}$.

Do tej pory sądowe przesłuchanie świadka w sposób przewidziany $\mathrm{w}$ regulacjach zawartych $\mathrm{w}$ art. 185a-185c k.p.k. stanowiło „sprawę pilną" w rozumieniu § 2 pkt 5 lit.a Regulaminu urzędowania sądów powszechnych ${ }^{32}$, co oznaczało, że termin posiedzenia w tym zakresie podlegał wyznaczeniu bez względu na kolejność wpływu do sądu. Regulacja ta nie zapewniała jednak w wystarczającym stopniu sprawnego i szybkiego przesłuchania ofiary przestępstw wymienionych $\mathrm{w}$ przepisach art. 185a i art. 185c k.p.k. Na konieczność skrócenia czasu oczekiwania na przesłuchanie pokrzywdzonego zwracał uwagę w swoich wystąpieniach Rzecznik Praw Obywatelskich. Jak wynika bowiem z treści pisma Rzecznika z dnia 17 lutego 2016 r. wystosowanego do Prokuratora Generalnego $^{33}$, w sprawach o przestępstwa z art. 197 k.k. od momentu zawiadomienia do czasu posiedzenia sądowego niejednokrotnie upływał okres przeszło $50 \mathrm{dni}$, co zdaniem Rzecznika nie zapewniało wystarczającej ochrony stanu zdrowia psychicznego świadka pokrzywdzonego. W odpowiedzi na wystąpienia Rzecznika Praw Obywatelskich ustawodawca wprowadził czternastodniowy instrukcyjny termin na dokonanie czynności przesłuchania pokrzywdzonego w charakterze świadka. Z uwagi na fakt, iż przesłuchanie w trybie określonym w przepisach

${ }^{28}$ M. SZYMAŃSKA-PytuIŃSKA, A. СHODECKA: Zagrożenia wtórnq wiktymizacja dziecka ofiary wykorzystywania seksualnego zwiazane z badaniami sadowymi. „Dziecko krzywdzone. Teoria, badania, praktyka" 2014, Vol. 13, nr 1, s. 73.

${ }^{29}$ Ibidem, s. 73.

30 Ibidem, s. 74-75.

${ }^{31}$ M. KIERSKI: Jednokrotne przestuchanie pokrzywdzonego $w$ trybie art. 185 a k.p.k. - zasada czy wyjątek?. Prok. i Pr. 2018, nr 11, s. 88.

32 Rozporządzenie Ministra Sprawiedliwości z dnia 23 grudnia 2015 r. Regulamin urzędowania sądów powszechnych, Dz.U. 2015, poz. 2316 ze zm.

${ }_{33}$ Pismo Rzecznika Praw Obywatelskich z dnia 17 lutego 2016 r. Źródło: https:// www.rpo.gov.pl/sites/default/files/Wyst \%C4\%85pienie\%20generalne\%20-\%20185c\%20 par.2\%20k.p.k\%2017.12.2015..pdf [dostęp: 15.06.2020]. 
art. 185a i 185c k.p.k. odbywa się na wniosek prokuratora, należy przyjąć, iż wskazany termin winno się liczyć od dnia wpływu wniosku prokuratora o przesłuchanie do sądu.

Regulacja ta zasługuje na aprobatę. Jak bowiem słusznie podkreślono w uzasadnieniu do projektu, sprawne i szybkie przesłuchanie pokrzywdzonego przestępstwami wymienionymi w powołanych przepisach ma na celu zredukowanie traumatycznych przeżyć i dyskomfortu psychicznego pokrzywdzonych małoletnich lub przestępstwami przeciwko wolności seksualnej ${ }^{34}$. Podkreślić przy tym należy, iż nie występuje podniesione $\mathrm{w}$ piśmiennictwie zagrożenie, iż wprowadzona regulacja de facto narzuca organom procesowym przeprowadzenie czynności z udziałem pokrzywdzonych w określonym terminie i niesie za sobą ryzyko zebrania niewystarczającej liczby dowodów i informacji ${ }^{35}$. Wprowadzony czternastodniowy termin nie wymusza bowiem na organach procesowych dokonania przesłuchania pokrzywdzonego $\mathrm{w}$ trybie wskazanym $\mathrm{w}$ art. 185a oraz 185c k.p.k. w ściśle określonym momencie postępowania, a jedynie powoduje konieczność przyspieszenia czynności organizacyjnych tak, aby od momentu wpłynięcia do sądu wniosku prokuratora do momentu przesłuchania pokrzywdzonego nie upłynęło więcej niż 14 dni. Na skutek wprowadzonej regulacji istotnemu przyspieszeniu będą zatem podlegały czynności w postaci rozpoznania przez sąd wniosku prokuratora o dokonanie czynności przesłuchania, wyznaczenia miejsca i terminu przesłuchania oraz wezwania wszystkich osób uprawnionych bądź zobowiązanych do stawiennictwa $\mathrm{w}$ trakcie przesłuchania, $\mathrm{tj}$. pokrzywdzonego, jego przedstawiciela ustawowego lub opiekuna faktycznego, pełnomocnika, psychologa oraz obrońcy podejrzanego, jeżeli postępowanie toczyć się będzie już przeciwko podejrzanemu. Organ prowadzący postępowanie przygotowawcze ze względu na zasadę jednokrotnego przesłuchania pokrzywdzonego przestępstwami z użyciem przemocy lub groźby bezprawnej lub przeciwko wolności, wolności seksualnej i obyczajności czy przeciwko rodzinie i opiece $\mathrm{w}$ dalszym ciągu będzie zobowiązany do zabezpieczenia możliwie obszernego materiału dowodowego pozwalającego na ustalenie okoliczności sprawy na tyle szeroko, aby nie było niebezpieczeństwa, że ujawnią się nowe, nieznane okoliczności jeszcze przed przystąpieniem do przesłuchania ${ }^{36}$. W doktrynie wskazuje się, że organ ścigania może dokonywać wstępnych ustaleń w sprawie na pod-

${ }^{34}$ Uzasadnienie projektu, s. 25.

35 Zob. Opinia Komisji Legislacyjnej przy Naczelnej Radzie Adwokackiej do projektu, s. 22. Źródło: https://www.ora-warszawa.com.pl/wp-content/uploads/2019/01/opinia_ KL_przy_NRA.pdf [dostęp: 15.06.2020].

${ }_{36}$ M. Kurowski. W: Kodeks postępowania karnego. T. I. Komentarz aktualizowany. Red. D. ŚWIECKI. LEX nr 581032. 
stawie np. przesłuchania dorosłego, który zawiadomił o przestępstwie, dokumentacji lekarskiej pokrzywdzonego i dopiero dysponując takim materiałem powinien wystąpić do sądu $\mathrm{z}$ wnioskiem o przesłuchanie pokrzywdzonego przestępstwem wymienionym w przepisie art. 185a k.p.k. bądź art. 185c k.p.k. ${ }^{37}$. Znowelizowana regulacja nie zwiększa zatem ryzyka ponownego przesłuchania pokrzywdzonego w stosunku do regulacji obowiązujących dotychczas.

Nie można jednak tracić z pola widzenia, że przesłuchania przeprowadzane w trybie przepisu art. 185a k.p.k. w praktyce często przeprowadzane są na etapie postępowania, w którym nie występuje jeszcze podejrzany, a, co za tym idzie, w przesłuchaniu nie uczestniczy jego obrońca. Z uwagi zatem na zastrzeżenie zawarte $\mathrm{w}$ przepisie art. 185a $\$ 1$ k.p.k. w takiej sytuacji konieczne będzie ponowne przesłuchanie pokrzywdzonego, jeżeli zażądał tego oskarżony, który nie miał obrońcy w czasie pierwszego przesłuchania. Na tę sytuację zwracano uwagę w orzecznictwie Sądu Najwyższego, w którym postulowano, aby do przesłuchania w trybie art. 185a k.p.k. dochodziło już po przedstawieniu zarzutu popełnienia przestępstwa, czyli w fazie postępowania przygotowawczego in personam, a nie we wstępnej fazie tego postępowania in rem. Wówczas istnieje bowiem możliwość wyznaczenia podejrzanemu obrońcy z urzędu, jeżeli nie posiada obrońcy $\mathrm{z}$ wyboru. $\mathrm{W}$ takich sytuacjach, w większości wypadków, będzie można poprzestać na jednorazowym przesłuchaniu małoletniego pokrzywdzonego, a prawo oskarżonego do obrony nie zostanie naruszone $^{38}$. Mając jednak na uwadze, że w praktyce przesłuchanie w trybie art. 185a k.p.k. często ma miejsce w fazie in rem, należy stwierdzić, że choć dostrzeżenie przez ustawodawcę konieczności ochrony pokrzywdzonych przed wtórną wiktymizacją w pełni zasługuje na akceptację, to w praktyce może okazać się, że projektowana regulacja nie wpłynie zasadniczo na przebieg postępowania karnego i tym samym nie spełni zamierzonego przez projektodawcę celu.

Co do zasady z aprobatą należy odnieść się do zrównania uprawnień pokrzywdzonego z art. 185c k.p.k. z pokrzywdzonym z art. 185a k.p.k. W piśmiennictwie podnoszono postulat zwiększenia uprawnień pokrzywdzonego, który w dniu przesłuchania ukończył piętnasty rok życia ${ }^{39}$.

37 T. Grzegorczyк: Kodeks Postępowania Karnego. Komentarz. Kraków 2003, s. 479.

38 Wyr. SN z dnia 24 listopada 2009 r., III KK 176/09. LEX nr 553885.

39 I. BodnarCZUK: Przestuchanie małoletniego $w$ procesie karnym $w$ trybie art. 185 a i 185 b k.p.k. „Wrocławskie Studia Erazmiańskie. Zeszyty Studenckie” 2009, nr 2, s. 324; M. Horna: Nowelizacja kodeksu postępowania karnego a ochrona matoletniego podczas przestuchania. „Dziecko krzywdzone. Teoria, badania, praktyka” 2014, Vol. 13, nr 14, s. 36. Postulat zwiększenia uprawnień pokrzywdzonego, który w chwili przesłuchania ukończył 15 lat, podnoszony był również przez Rzecznika Praw Obywatelskich - zob. 
W konsekwencji wprowadzonych zmian również pokrzywdzonego przestępstwem z art. 197-199 k.k., który w chwili przesłuchania ukończył 15 lat, można będzie przesłuchać tylko wtedy, gdy jego zeznania mogą mieć istotne znaczenie dla rozstrzygnięcia sprawy, i tylko raz, chyba że wyjdą na jaw istotne okoliczności, których wyjaśnienie wymaga ponownego przesłuchania, zaś przesłuchanie winno odbywać się z udziałem psychologa. Utrzymano regulację, zgodnie z którą ponowne przesłuchanie, na wniosek pokrzywdzonego, przeprowadza się w sposób wskazany w art. 177 § 1a k.p.k., gdy zachodzi uzasadniona obawa, że bezpośrednia obecność oskarżonego przy przesłuchaniu mogłaby oddziaływać krępująco na zeznania pokrzywdzonego lub wywierać negatywny wpływ na jego stan psychiczny.

Wprowadzona nowelizacja $\mathrm{w}$ istocie oznacza, że co do zasady pokrzywdzonego wskazanego w przepisie art. 185c k.p.k. nie powinno się przesłuchiwać w charakterze świadka, chyba że jego zeznania mogą mieć istotne znaczenie dla rozstrzygnięcia sprawy. Takie przesłuchanie winno stanowić jednak ostatecznośćc ${ }^{40}$. Rozwiązanie to ma na celu objęcie ochroną przed wtórną wiktymizacją również pełnoletnich pokrzywdzonych przestępstwami przeciwko wolności seksualnej. Jak już bowiem zaznaczono powyżej, zagrożenie wtórną wiktymizacją związane z udziałem pokrzywdzonego $\mathrm{w}$ postępowaniu karnym nie dotyczy wyłącznie ofiar małoletnich. Na aprobatę zasługuje zatem wprowadzenie zasady jednokrotnego przesłuchania z udziałem psychologa również pokrzywdzonych wskazanych w art. 185c k.p.k.

Wymaga zaznaczenia, że $\mathrm{w}$ przeciwieństwie do regulacji przepisu art. 185a $§ 1$ k.p.k. ustawodawca zezwala na odstępstwo od zasady jednokrotnego przesłuchania wyłącznie w sytuacji, gdy w toku dalszego postępowania wyjdą na jaw istotne okoliczności, których wyjaśnienie wymaga ponownego przesłuchania. Brak jest natomiast przesłanki przesłuchania pokrzywdzonego z uwagi na żądanie oskarżonego, który nie miał obrońcy w czasie pierwszego przesłuchania pokrzywdzonego. Stanowi to zatem znaczące ograniczenie prawa do obrony oskarżonego, zgodnie z którym, jak wskazał Sąd Najwyższy w wyroku z dnia 6 lipca 2006 r. ${ }^{41}$, oskarżony musi mieć możliwość wnioskowania powtórnego przesłuchania pokrzywdzonego, co wynika ze standardu określonego w przepisie art. 6

pismo Rzecznika Praw Obywatelskich z dnia 16 kwietnia 2018 r. Źródło: https:// www.rpo.gov.pl/sites/default/files/Wyst \% C4\% 85 pienie $\% 20$ do\%20Ministra $\% 20$ Sprawiedliwo\%C5\%9Bci\%20ws.\%20procedury\%20przes\%C5\%82ucha\%C5\%84\%20 ofiar\%20przest\%C4\%99pstw\%20seksualnych\%20\%20.pdf [dostęp: 15.06.2020].

40 R.A. STEFAŃsKi. W: Kodeks postępowania karnego. T. II: Komentarz do art. 167-296. Red. R.A. STEFAŃsKi, S. ZAbŁocki. LEX nr 10826.

${ }^{41}$ Wyr. SN z dnia 6 lipca 2006 r., IV KK 226/06. LEX nr 219845. 
ust. 3 Konwencji o ochronie praw człowieka i podstawowych wolności, regulującego prawo do obrony. W sytuacji konieczności przeprowadzenia ponownego przesłuchania pokrzywdzonego w kolizji z jego ochroną staje zatem zasada prawdy oraz prawa do obrony oskarżonego. Jak wskazuje się $\mathrm{w}$ orzecznictwie, naruszeniem prawa do obrony będą sytuacje przesłuchiwania $\mathrm{w}$ postępowaniu przygotowawczym pokrzywdzonego $\mathrm{w}$ warunkach $\mathrm{z}$ art. 185a k.p.k., zastosowanych w drodze omawianej nowelizacji do pokrzywdzonego określonego w art. 185c k.p.k., zanim doszło do postawienia zarzutów konkretnej osobie, a zachodzą podstawy do postawienia takiego zarzutu. Takie działanie może bowiem prowadzić do sytuacji, w której nastąpi istotne ograniczenie prawa do obrony, bowiem ani oskarżony, ani jego obrońca nie będą mogli weryfikować sposobu przeprowadzenia tego dowodu ${ }^{42}$. W przypadku jednak przesłuchania małoletniego pokrzywdzonego określonego w przepisie art. 185a k.p.k. ustawodawca przewidział możliwość złożenia wniosku o ponowne przesłuchanie pokrzywdzonego przez oskarżonego, który nie miał należycie zagwarantowanego prawa do obrony w trakcie tej czynności. Brak analogicznego rozwiązania w przypadku przesłuchania pokrzywdzonego określonego $\mathrm{w}$ przepisie art. 185c k.p.k. stanowi zatem znaczące ograniczenie prawa do obrony. $\mathrm{O}$ ile zatem na aprobatę zasługuje zwiększenie ochrony pokrzywdzonego przestępstwami określonymi w przepisach art. 197-199 k.k. poprzez wprowadzenie zasady jednokrotnego jego przesłuchania w terminie 14 dni od złożenia wniosku oraz obligatoryjnego udziału psychologa w czynności, o tyle nie może się to odbywać kosztem podstawowych praw oskarżonego.

Rozważając kwestię przesłuchania małoletnich pokrzywdzonych, należy nadto zwrócić uwagę na regulację zawartą w przepisie art. 185a $\S 4$ k.p.k., która odnosi się do małoletnich pokrzywdzonych przestępstwami określonymi $\mathrm{w}$ przepisie $\S 1$, jeżeli $\mathrm{w}$ chwili przesłuchania ukończyli oni 15 lat. Ustawodawca pozostawił regulację, zgodnie z którą takiego pokrzywdzonego przesłuchuje się w warunkach określonych $\mathrm{w} \S 1-3$, jeżeli zachodzi uzasadniona obawa, że przesłuchanie $\mathrm{w}$ innych warunkach mogłoby wywrzeć negatywny wpływ na jego stan psychiczny. Jednocześnie wyłączył $\mathrm{w}$ takim przypadku możliwość zastosowania przesłuchania w warunkach określonych w przepisie art. 185c k.p.k., co w istocie oznacza, że w przypadku małoletniego pokrzywdzonego przestępstwem wymienionym w art. 185a §1 k.p.k., który w chwili przesłuchania ukończył 15 lat, jeżeli zachodzi uzasadniona obawa, że przesłuchanie w innych warunkach mogłoby wywrzeć negatywny wpływ na jego stan psychiczny, zastosowanie mają szczegółowe regulacje zawarte w przepisie art. $185 \mathrm{a}$

${ }^{42}$ Post. SN z dnia 9 listopada 2016 r., V KK 273/16. Legalis. 
§1 k.p.k., odnoszące się do przesłuchania małoletniego pokrzywdzonego, który w chwili przesłuchania nie ukończył 15 lat.

Skupiając się na zmianach wpływających na pozycję pokrzywdzonego $\mathrm{w}$ procesie karnym, niezbędne jest również zwrócenie uwagi na przepis art. 315a k.p.k., zgodnie z którym od przesłuchania pokrzywdzonego w charakterze świadka można odstąpić, jeżeli czynność ta nie będzie niezbędna do dokonania ustaleń faktycznych. Pokrzywdzony, który nie był przesłuchany w postępowaniu, powinien zostać przesłuchany w charakterze świadka, jeżeli tego zażąda, chyba że uwzględnienie żądania prowadziłoby do przewlekłości postępowania. Bezpośrednio skorelowana $\mathrm{z}$ tą regulacją jest zmiana przepisu art. 300 § 2 k.p.k. określającego kwestię pouczenia pokrzywdzonego o przysługujących mu uprawnieniach oraz przepisu art. 325h k.p.k. przewidującego odpowiednie stosowanie przepisu art. 315a k.p.k. w znowelizowanym brzmieniu. Regulacja przewidziana w art. 315a k.p.k. ma być kolejnym narzędziem przyspieszenia postępowania, realizując podstawowe założenie nowelizacji ${ }^{43}$. Z uzasadnienia wynika, że przepis ten ma znaleźć zastosowanie w sprawach, w których występuje większa liczba osób pokrzywdzonych, a sprawca posługiwał się podobnym modus operandi. W sytuacji, gdy osoba pokrzywdzonego nie stanowi przedmiotu czynności wykonawczej, a pokrzywdzony nie był świadkiem przestępstwa, najczęściej nie posiada on informacji mogących mieć istotne znaczenie dla toczącego się postępowania, zatem jego przesłuchanie nie tylko nie jest niezbędne, ale również prowadzi do przedłużenia postępowania i zwiększenia jego kosztów. Z powyższymi założeniami co do zasady należy się zgodzić, w wielu wypadkach przesłuchanie wszystkich pokrzywdzonych przestępstwem nie prowadzi bowiem do wzbogacenia materiału dowodowego $\mathrm{w}$ prowadzonym postępowaniu. Ustawodawca jako przykłady takich spraw podaje przywłaszczenie i sprzeniewierzenie cudzego mienia (art. 284 § 1 i 2 k.k.), oszustwo (art. 286 § 1 k.k.) oraz tzw. oszustwo komputerowe (art. $287 \S 1$ k.k.). Należy jednak zauważyć, że przepis art. 315a k.p.k. nie zawiera w swej treści katalogu spraw, w których odstąpienie od przesłuchania jest możliwe, dlatego nie można wykluczyć sytuacji, w której instytucja ta będzie nadużywana, pomimo braku faktycznej potrzeby pominięcia zeznań pokrzywdzonego. Można zatem zastanowić się, czy omawiana regulacja nie powinna w bardziej szczegółowy sposób zakreślać katalogu spraw, w których dopuszczalne będzie odstąpienie od przesłuchania pokrzywdzonego w charakterze świadka, na przykład wskazując, że jest to możliwe w sytuacji, gdy liczba pokrzywdzonych jest znaczna.

\footnotetext{
${ }^{43}$ Uzasadnienie projektu, s. 1.
} 
Zgodnie z brzmieniem omawianego przepisu przesłuchanie pokrzywdzonego jest jednak konieczne, jeśli zgłosi on takie żądanie. W uzasadnieniu projektu podkreślono, że wyrażenie jego woli w postaci „żądania”, a nie „wniosku”, ma eksponować imperatywny charakter stanowiska pokrzywdzonego, które organ będzie musiał uwzględnić. Żądanie to nie zostanie jednak zrealizowane, jeżeli uczynienie mu zadość będzie prowadziło do przewlekłości postępowania. Ustawodawca pozostawia zatem organowi prowadzącemu postępowanie pełną swobodę w zakresie przeprowadzenia tej czynności. Należy przy tym zauważyć, że decyzja prokuratora lub organu prowadzącego postępowanie przygotowawcze nie podlega kontroli instancyjnej, ponieważ nie jest dopuszczalne jej zaskarżenie (arg. ex art. 459 k.p.k. w zw. z art. 465 k.p.k.). Wbrew temu, co wskazano w uzasadnieniu projektu ustawy, regulacja ta nie pozostaje w zgodzie z założeniami Dyrektywy Parlamentu Europejskiego i Rady z dnia 25 października 2012 r. ustanawiającej normy minimalne w zakresie praw, wsparcia i ochrony ofiar przestępstw ${ }^{44}$. Zgodnie $\mathrm{z}$ art. 10 tego aktu państwa członkowskie mają obowiązek zapewnić ofiarom przestępstw możliwość bycia wysłuchanymi w toku postępowania karnego i obowiązek ten ma charakter bezwzględny. W sytuacji zatem, gdy żądanie przesłuchania pokrzywdzonego nie zostanie uwzględnione $\mathrm{z}$ uwagi na przewlekłość postępowania, standard ochrony będzie niższy niż minimalny, przewidziany w wiążących Polskę europejskich aktach prawnych. Wprowadzenie kryterium przewlekłości postępowania decydującego o dopuszczalności uwzględnienia żądania pokrzywdzonego budzi poważne wątpliwości, sprawia bowiem wrażenie, że ustawodawca przedkłada szybkość postępowania nad ustalenie okoliczności popełnienia przestępstwa i jego skutków. Należy zatem odnieść się do treści przepisu art. 315a k.p.k. z pewną dozą sceptycyzmu. O ile trzeba zgodzić się z tym, że przesłuchiwanie wszystkich pokrzywdzonych w każdej sprawie nie zawsze jest konieczne i nierzadko takie zeznania nie wzbogacają w jakimkolwiek stopniu materiału dowodowego, to jednak wydaje się, że w wypadku, gdy pokrzywdzony chce być wysłuchany i tego żąda, należy mu to umożliwić ${ }^{45}$. Tym samym, aby zaakceptować tę regulację, przepis art. 315a k.p.k. musiałby zostać pozbawiony zastrzeżenia o możliwości nieuwzględnienia żądania pokrzywdzonego z uwagi na skutek w postaci przewlekłości postępowania.

Pozytywnie należy natomiast ocenić zmianę zwiększającą uprawnienia pokrzywdzonego $\mathrm{w}$ sytuacji wydania wyroku nakazowego. Dotychczas pokrzywdzony mógł zgłosić zamiar występowania w postę-

${ }^{44}$ Dz.U. UE L z dnia 14 listopada 2012 r.

45 Por. Opinia OBSiL KRRP, s. 20-21. 
powaniu $\mathrm{w}$ charakterze oskarżyciela posiłkowego po wniesieniu aktu oskarżenia przez oskarżyciela publicznego aż do czasu rozpoczęcia przewodu sądowego na rozprawie głównej (art. 54 §1 k.p.k.). Z uwagi na brak rozprawy, którą w postępowaniu nakazowym zastępuje posiedzenie, oświadczenie to mogło być złożone do czasu wydania wyroku nakazowego, przy czym pokrzywdzonego nie zawiadamiano o możliwości zakończenia postępowania w tym trybie. O ile o wniesieniu zasadniczej skargi karnej pokrzywdzony jest zawiadamiany przez oskarżyciela publicznego (art. $334 \$ 3$ k.p.k.), o tyle brak było w Kodeksie postępowania karnego normy zobowiązującej do zawiadomienia pokrzywdzonego o posiedzeniu, na którym wydany miał zostać wyrok nakazowy. Pokrzywdzony, zwłaszcza występujący bez pełnomocnika, mógł być zatem przekonany o możliwości przystąpienia do postępowania w dalszym jego toku, podczas gdy droga do wykorzystania tego uprawnienia została już zamknięta. W orzecznictwie rozważano możliwość wniesienia sprzeciwu od wyroku nakazowego pomimo niedochowania terminu do złożenia oświadczenia o występowaniu w charakterze oskarżyciela posiłkowego, Sąd Najwyższy stwierdził jednak, że ,istotne jest nie to, czy pokrzywdzony »zachowuje uprawnienia strony ", lecz to, czy jest (stał się) on oskarżycielem" ${ }^{46}$. Tym samym uprawnienie do wniesienia sprzeciwu nie mogło zostać przyznane osobie, która, co prawda, oskarżycielem nie była, ale mogła ubiegać się o status oskarżyciela posiłkowego w procesie karnym. Analiza dotychczas obowiązującego stanu prawnego prowadzi do wniosku, że prawo do występowania w postępowaniu w charakterze oskarżyciela posiłkowego było wyjątkowo słabo zagwarantowane z uwagi na niezwykle krótki termin na złożenie przez pokrzywdzonego stosownego oświadczenia ${ }^{47}$. Można nawet stwierdzić, że ukształtowanie przepisów w taki sposób powodowało, że uprawnienie to $\mathrm{w}$ rzeczywistości było wręcz pozorne ${ }^{48}$.

Przepis art. 505 k.p.k. w aktualnym brzmieniu przewiduje natomiast, że odpis wyroku nakazowego doręczany jest także pokrzywdzonemu wraz z informacją o możliwości zaskarżenia wydanego orzeczenia. Warunkiem dla wniesienia przez pokrzywdzonego sprzeciwu jest złożenie, najpóźniej wraz ze środkiem zaskarżenia, oświadczenia o występowaniu w sprawie w charakterze oskarżyciela posiłkowego. Powyższa zmiana wzmocni pozycję procesową pokrzywdzonego i urealni jego uprawnienia w procesie karnym, spełniając standardy konstytucyjne w zakresie zagwarantowania prawa do sądu oraz ukształtowania procesu karnego w zgodzie z zasa-

46 Post. SN z dnia 24 września 1997 r., I KZP 13/97. OSNKW 1997, nr 11-12, poz. 100 .

${ }^{47}$ P. KarolczYK: Sprzeciw od wyroku nakazowego. Prok. i Pr. 2006, nr 7-8, s. 87.

48 Wystapienie Rzecznika Praw Obywatelskich z 11.09.2017 r. do Sekretarza Stanu w Kancelarii Prezydenta RP, sygn. VII.510.45.2017.AJK, s. 4. 
dami sprawiedliwości proceduralnej ${ }^{49}$. Należy zatem odnieść się do niej z pełną aprobatą.

Podsumowując powyższe rozważania $\mathrm{w}$ zakresie zmian zawartych w ustawie z dnia 19 lipca 2019 r., w pierwszej kolejności docenić należy dostrzeżenie przez ustawodawcę znaczenia regulacji dotyczących uprawnień pokrzywdzonego $\mathrm{w}$ procesie karnym. Jak już bowiem zaznaczono na wstępie, dla zapewnienia standardu rzetelnego postępowania niezbędne jest nie tylko zapewnienie realizacji prawa do obrony, ale także należytej pozycji procesowej pokrzywdzonego. W tym celu konieczne jest ukształtowanie procedury karnej w sposób gwarantujący właściwą realizację praw pokrzywdzonego w toku całego postępowania. Mając na względzie wnioski poczynione powyżej, należy stwierdzić, iż część znowelizowanych regulacji zasługuje na akceptację, a ich wprowadzenie należy uznać za w pełni uzasadnione. Niemniej jednak, jak już zostało zaznaczone, niektóre ze zmian budzą wątpliwości, wobec czego wskazane byłoby ich ponowne rozważenie oraz zmiana w sposób, który zapewni urzeczywistnienie praw pokrzywdzonego, nie naruszając przy tym innych istotnych standardów procesowych.

\section{Bibliografia}

\section{Literatura}

BIEDERMAN A.: Rzetelna informacja a aktywność pokrzywdzonego $w$ procesie karnym. Prok. i Pr. 2007, nr 4.

Beachnio-Parzych A., Kosonoga J.: Rzetelny proces karny $w$ orzecznictwie Sadu Najwyższego. W: Rzetelny proces karny. Red. P. WiLIŃski. Warszawa 2009.

BODNARCZUK I.: Przestuchanie matoletniego $w$ procesie karnym $w$ trybie art. $185 a$ i 185 b.p.k. „Wrocławskie Studia Erazmiańskie. Zeszyty Studenckie” 2009, nr 2.

DudKa K., Artymiak G.: Sytuacja pokrzywdzonego w procesie karnym, ze szczególnym uwzględnieniem roli oskarżyciela positkowego i powoda cywilnego. Instytut Wymiaru Sprawiedliwości. Warszawa 2012.

GrzegorczyK T.: Kodeks Postępowania Karnego. Komentarz. Kraków 2003.

Horna M.: Nowelizacja kodeksu postępowania karnego a ochrona matoletniego podczas przestuchania. „Dziecko krzywdzone. Teoria, badania, praktyka” 2014, Vol. 13, nr 14.

KarolczYK P.: Sprzeciw od wyroku nakazowego. Prok. i Pr. 2006, nr 7-8.

KIERSKI M.: Jednokrotne przestuchanie pokrzywdzonego $w$ trybie art. 185 a k.p.k. zasada czy wyjątek?. Prok. i Pr. 2018, nr 11.

Kulesza C. W: Kodeks postępowania karnego. Komentarz. Red. K. DudKa. LEX nr 10800.

49 Opinia OBSiL KRRP, s. 31. 
KUROwsKi M. W: Kodeks postępowania karnego. T. I. Komentarz aktualizowany. Red. D. ŚwIECKI. LEX nr 581032.

LiMAŃsKA A.: Brak obowiazku stawiennictwa oskarżyciela publicznego na rozprawie $w$ kontekście podstawowych zasad procesu karnego. Probl. Prawa Karnego 2018, nr 2(28).

Nowicki K. W: Kodeks postępowania karnego. Komentarz. Red. J. SкоRUPкA. Warszawa 2015.

NowIKOWsкi I.: Kontrola merytoryczna oświadczenia strony o odwołaniu czynności procesowej. Annales UMCS 1996, Vol. XLIII.

Proces karny. Red. K. Marszae, J. ZagrodnIK. Warszawa 2017.

Skowron B. W: Kodeks postępowania karnego. Komentarz. Red. K. DudKa. LEX nr 10800.

Stefański R.A. W: Kodeks postępowania karnego. T. II. Komentarz do art. 167-296. Red. R.A. STEFAŃSKI, S. ZabŁocKi. LEX nr 10826.

SZYMAŃSKa-PyTLIŃSKa M., CHODECKa A.: Zagrożenia wtórna wiktymizacją dzieckaofiary wykorzystywania seksualnego zwiazane z badaniami sadowymi. „Dziecko krzywdzone. Teoria, badania, praktyka" 2014, Vol. 13, nr 1.

ZAGRODNIK J.: Instytucja skargi subsydiarnej w procesie karnym. Warszawa 2005.

ZAGRODNIK J:: Udziat prokuratora $w$ postępowaniu sq̨dowym wszczętym przez oskarżyciela positkowego subsydiarnego. Prok. i Pr. 2017, nr 2.

\section{Orzecznictwo}

Post. SN z dnia 24 września 1997 r., I KZP 13/97. OSNKW 1997, nr 11-12, poz. 100.

Post. SN z dnia 9 listopada 2016 r., V KK 273/16. Legalis.

Wyr. SN z dnia 6 lipca 2006 r., IV KK 226/06. LEX nr 219845.

Wyr. SN z dnia 24 listopada 2009 r., III KK 176/09. LEX nr 553885.

Wyr. TK z dnia 16 maja 2018 r., K 12/15, Dz.U. 2018 r., poz. 942.

\section{Źródła internetowe}

Pismo Rzecznika Praw Obywatelskich z dnia 17 lutego 2016 r. Źródło: https:// www.rpo.gov.pl/sites/default/files/Wyst\%C4\%85pienie\%20generalne $\% 20$ -\%20185c\%20par.2\%20k.p.k\%2017.12.2015..pdf [dostęp: 15.06.2020].

Pismo Rzecznika Praw Obywatelskich z dnia 16 kwietnia 2018 r. Źródło: https:// www.rpo.gov.pl/sites/default/files/Wyst\%C4\%85pienie\%20do\%20Ministra \%20Sprawiedliwo \%C5\%9Bci\%20ws.\%20procedury\%20przes\%C5\%82 ucha\%C5\%84\%20ofiar\%20przest \%C4\%99pstw\%20seksualnych\%20\%20. pdf [dostęp: 15.06.2020].

Sprawozdania Prokuratury Krajowej z działalności powszechnych jednostek organizacyjnych prokuratury w sprawach karnych. Źródło: https://pk.gov.pl/ dzialalnosc/sprawozdania-i-statystyki/ [dostęp: 15.06.2020].

\section{Źródła inne}

Opinia Komisji Legislacyjnej przy Naczelnej Radzie Adwokackiej do projektu. Źródło: https://www.ora-warszawa.com.pl/wp-content/uploads/2019/01/opi nia_KL_przy_NRA.pdf [dostęp: 15.06.2020]. 
Opinia OBSiL KRRP z 17.12.2018 r. do projektu ustawy o zmianie ustawy Kodeks postępowania karnego oraz niektórych innych ustaw. Źródło: http:// obsil.pl/wp-content/uploads/2018/12/Opinia-OBSiL-z-17.12.2018-r.-projekt -zmian-KPK.pdf [dostęp: 15.06.2020].

Wystapienie Rzecznika Praw Obywatelskich z 11.09.2017 r. do Sekretarza Stanu w Kancelarii Prezydenta RP, sygn. VII.510.45.2017.AJK. Źródło: https:// www.rpo.gov.pl/sites/default/files/Co\%20warto\%20zmienia $\%$ C4\%87\%20 w\%20polskich\%20s\%C4\%85dach\%20-\%20RPO\%20do\%20Min.\%20 w\%20Kancelarii\%20Prezydenta\%2011.09.2017.pdf [dostęp: 15.06.2020]. 